\title{
Effect of Promotion and Price on Customers' Purchase Interests at PT Sumber Cipta Multiniaga, South Jakarta Branch
}

\author{
Juhaeri \\ Universitas Pamulang \\ Email: juhaeri@unpam.ac.id
}

(Received: January 10-2020; revised: February 13-2020; published: June 30-2020)

\begin{abstract}
This study aims to determine the effect of promotion and price on customer buying interest at PT. Sumber Cipta Multiniaga South Jakarta Branch. The method uses explanatory research and hypothesis testing with survey techniques, by distributing questionnaires using a saturated sampling technique of 100 respondents. The analytical tool used is descriptive and verification analysis or inverential with the test instruments and classical assumptions. The statistical analysis uses multiple regression tests, correlation coefficient values, coefficient of determination and hypothesis testing. The results of the study are promotion and a significant positive effect with a correlation of 0.576 and determination of $33.2 \%$. Hypothesis testing obtained $\rho$ value $0,000<0.05$. Price has a positive and significant effect on customer buying interest, with a correlation value of 0.645 and a determination of $41.6 \%$. Hypothesis testing obtained $\rho$ value $0,000<0.05$. Promotion and price simultaneously have a positive and significant effect on customer buying interest with a correlation value of 0.695 and a determination of $48.3 \%$ while the remaining $53.1 \%$ is influenced by other factors not examined. Hypothesis testing obtained $\rho$ value 0,000 $<0.05$.
\end{abstract}

Keywords: Promotion, price, customer buying interest.

\section{INTRODUCTION}

Along with the development of today's era, it is not spared also followed by the growth and birth of companies, both those struggling in the field of goods and services where every company always strives as much as possible to get and maintain existing market share. This can make competition more intense, especially for business people. Companies can be said to be successful or win in competition if the company is successful in getting and retaining customers that they have previously targeted (Peter, Olson, \& Grunert, 1999; Sumarwan, 2003; Sutisna, 2003)

The large number of customers means that the company will get big profits and better growth. Basically, the increasing number of competitors in a particular field, the more considerations that must be chosen by consumers because the more products offered. Surely these consumers will choose products or services that are in accordance with their wants and needs. Therefore companies are demanded to be more innovative in producing goods and services in accordance with what is desired and needed by their prospective customers to attract consumers' attention and face competition from competitors (Hasnelly \& Yusuf, 2012; Minarti \& Segoro, 2014 ; Purnasari \& Yuliando, 2015). 


\author{
36 Jurnal Ilmiah Ilmu Administrasi Publik: Jurnal Pemikiran dan Penelitian Administrasi Publik \\ Volume 10 Number 1, January- june 2020. Page 35-44
}

Besides price, factors that influence consumer buying interest are promotion (Eko Purnomo, 2016; Morris, 1980; Satria, 2017; Scriven, Clemente, Dawes, Trinh, \& Sharp, 2017). Promotion is an important factor in realizing a company's sales goals (Deng, Staelin, Wang, \& Boulding, 2018; Morris, 1980; Scriven et al., 2017). With the promotion of the company can communicate a wide range of products to its customers. The advantages of the product can be known by consumers and can make consumers interested in trying and then will make the decision to buy a product .

The constraints faced by PT Sumber Cipta Multiniaga in carrying out their promotional strategies apart from competitive competitors in conducting field promotions, very little and limited space provided for the installation of promo tools plus the role of the government itself was very influential by limiting the promotion of cigarettes with PP number 109 in 2012 this makes PT Sumber Cipta Multiniaga must be smart to anticipate every promotion that is carried out.

The purchase pattern for each household is different, because every household has different types of expenditure from primary, secondary and tertiary needs. It is this type of expenditure that ultimately forms a household lifestyle, where the lifestyle of each household is different and this makes the reason why the percentage of income of a household for each type of household expenditure is different, for example for households that consume cigarettes certainly have a difference when compared to households that do not consume cigarettes.

It is known that there has been a phenomenon of the difference between the target promotional activities and their realization. Promotional activity targets that have been set cannot be realized to the maximum with the company's budget. The market share in the South Jakarta region is controlled by the A Mild cigarette brand with a market share of $20 \%$, in second place is the Djarum Super cigarette brand by $13 \%$, ranked third is the Gudang Garam International cigarette brand with a market share of $12 \%$, and ranked most recently there was the 234 Magnum Filter cigarette brand with a market share of 1\%. PT Sumber Cipta Multiniaga is demanded to be able to offer or improve the quality of products that are superior to competitors by way of Promotion, so as to increase consumer buying interest towards the products offered. Manufacturers should maintain product availability and speed of product turnover, as well as improve and further highlight product quality, consistency, quality, brand image and others in order to support in influencing consumer buying interest.

According to (Sandi Winarto et al., 2012) price is an important part that is inseparable from the marketing mix. Because it also cannot be separated from the other three components of the marketing mix, namely product, distribution and sales promotion. Therefore, in developing a pricing strategy the company cannot ignore the short and medium term marketing policies outlined as well as the product, distribution and sales promotion strategies. Besides that, like the marketing mix, the price strategy needs to take into account the perception of the target consumer to whom the strategy is intended and the development of the business environment. It is known that there are fluctuations in product prices from year to year PT Sumber Cipta Multiniaga always positions prices above competitors of similar products, but these prices do not make the turnover and market progress sharply higher. 
According to (Kotler \& Keller, 2009) consumer buying interest is a consumer behavior where consumers have the desire to buy or choose a product, based on experience in choosing, using and consuming or even wanting a product.

Promotion is not only an activity in recognizing a product or service, but promotion is also an activity that can change consumer behavior so that consumers can buy the product and remain familiar with the product or service (Al Badi, 2015; Kasali, 1992; Suardana, Sunni, \& Ridwan, 2020). Besides that, promotion is a milestone of the company in creating sales for its products and services.

In general, companies engaged in the retail sector if the sales volume obtained is low, the profits from the products sold will also be low. This has a directly proportional relationship between the volume of sales sold with company income.

According to (Lupiyoadi, 2013) promotion is an activity carried out by the company to communicate the benefits of the product and as a tool to influence consumers in purchasing or using services in accordance with needs. Based on the background of the problem that has been explained, the writer is interested in conducting research with the title "The Effect of Promotion and Price on Customer Purchase Interest in PT Sumber Cipta Multiniaga Case Study of PT Sumber Cipta Multiniaga, South Jakarta Branch".

\section{METHOD}

This research was conducted at PT. Sumber Cipta Multiniaga South Jakarta Branch. Objects that are determined through a certain criteria that will be categorized into objects that will be examined. According to (Sugiyono, 2012), population is the number of generalized areas consisting of objects or subjects that have the quality and characteristics determined by the researcher and then conclusions are drawn. The population in this study were customers of PT. Sumber Cipta Multiniaga South Jakarta Branch. (Arikunto, 2010) argues that, the sample is part or representative of the population under study. In this study the sample used was 100 respondents.

Data collection methods used are questionnaires, surveys and literature studies Data analysis methods used in this research are test instruments consisting of validity and reliability tests. Validity test is intended to determine the accuracy of the data about the compatibility between what you want measured with the results of the measurement. According to (Ghozali, 2018), a questionnaire is said to be valid if the questions on the questionnaire are able to reveal something that will be measured by the questionnaire. To test the validity seen from the ItemTotal Statistics table. This value is compared with the Alpha 0.30 Chronbatch standard. Criteria or conditions for instrument decision provisions are said to be valid and invalid according to (Ghozali, 2018) by comparing the Alpha Chronbatch value with the Alpha critical point 0.30 with the provisions, if the Alpha Chronbatch value $>0.30$, then the instrument is valid, and if the value Alpha chronbatch $<0.30$, then the instrument is invalid. The reliability test analysis model used in this study is the Cronbach Alpha model. According to (Ghozali, 2018), reliability is a tool to test the consistency of respondents' answers to questions in the questionnaire. A questionnaire is said to be reliable if a person's answer to a question is consistent or stable over time. Measurements were made once and reliability using the Cronbach Alpha $(\alpha)$ statistical test. In the measurement of one shot will be done by Cronbach's Alpha analysis. 
38 Jurnal Ilmiah Ilmu Administrasi Publik: Jurnal Pemikiran dan Penelitian Administrasi Publik
Volume 10 Number 1, January- june 2020. Page 35-44

The classic assumption test is intended to determine the accuracy of a data. According to (Santoso, 2012), a regression model will be used for forecasting, a good model is a model with minimum forecasting errors. Therefore, a model before use should fulfill a number of assumptions, commonly called classical assumptions. In this study the classic assumption tests used include: Normality Test, Multicollinearity Test, Autocorrelation Test, and Heterokedasticity Test. Furthermore, descriptive statistical analysis and verification analysis are performed.

\section{RESULT AND DISCUSSION}

PT Sumber Cipta Multiniaga as a distributor must look further into the various factors that influence buyers and develop an understanding of how consumers make purchasing decisions. Specifically, marketers must identify the person who makes the purchase decision, the type of purchasing decision, and the steps in the buying process.

\section{Descriptive Analysis}

Descriptive analysis is intended to provide an overview of the results of research in general, how respondents assess the variables studied. Weighing the scores of the variables studied.

\section{Table 1}

Evaluation of Respondents for each Variable

\begin{tabular}{ll}
\multicolumn{1}{c}{ Variabel } & Rata-rata Skor \\
\hline Promotion (X1) & 3,83 \\
Price (X) & 3,86 \\
Customer Purchase Interest (Y) & 3,94 \\
\hline
\end{tabular}

Source: Primary data processed

Based on the codding results in the table above, the promotion variable score was 3.83 , the price was 3.86 and the Customer Purchase Interest was 3.94.

\section{Multiple Linear Regression Analysis}

Multiple regression analysis is intended to find out how much influence the promotion variable (X1) and price (X2 on Customer Purchase Interest (Y). 


\section{Table 2}

\section{Multiple Linear Regression Test Results}

\section{Coefficients $^{\mathrm{a}}$}

\begin{tabular}{|c|c|c|c|c|c|}
\hline \multirow[t]{2}{*}{ Model } & \multicolumn{2}{|c|}{$\begin{array}{l}\text { Unstandardized } \\
\text { Coefficients }\end{array}$} & \multirow{2}{*}{$\begin{array}{c}\begin{array}{c}\text { Standardized } \\
\text { Coefficients }\end{array} \\
\text { Beta }\end{array}$} & \multirow[t]{2}{*}{$\mathrm{t}$} & \multirow[t]{2}{*}{ Sig. } \\
\hline & B & Std. Error & & & \\
\hline (Constant) & 11.372 & 2.944 & & 3.862 & .000 \\
\hline Promotion (X1) & .271 & .077 & .312 & 3.534 & .001 \\
\hline Price $(\mathrm{X} 2)$ & .456 & .086 & .470 & 5.321 & .000 \\
\hline
\end{tabular}

Source: Primary data processed

Based on the calculation results in the table above can be presented in the form of a standardized regression equation as follows: $\mathrm{Y}=11,373+0,271 \mathrm{X} 1+0,456 \mathrm{X} 2$. Constant value was obtained at 11,373 , stating that without being influenced by the promotion and price variables, the value of customer purchase interest has been formed at 11.373 points. Promotion (X1) has a positive and significant effect on Customer Purchase Interest (Y) with a coefficient value of 0.271 . This means that if the promotion variable (x1) increases by one unit assuming the price variable (X2) is fixed or constant (0), then the Customer Purchase Interest (Y) will also increase by 0.271 points. Price $(\mathrm{X} 2)$ has a positive and significant effect on customer buying interest (y) with a coefficient value of 0.456 . This means that if the price (X2) increases by one unit assuming the variable promotion (X1) is constant, then the Customer Purchase Interest $(\mathrm{Y})$ will also increase by 0.456 points.

\section{Correlation Coefficient Analysis}

The correlation coefficient is used to determine the level of influence strength of the independent variables on the dependent variable.

Table 3

\section{Correlation Coefficient Test Results Influence of Promotion of Customer Purchase} Interest

\section{Correlations $^{\mathbf{b}}$}

\begin{tabular}{llcc}
\hline & & Promotion (X1) & $\begin{array}{c}\text { Customer Purchase } \\
\text { Interest (Y) }\end{array}$ \\
\hline Promotion (X1) & Pearson Correlation & 1 & $.576^{* *}$ \\
& Sig. (2-tailed) & $.576^{* *}$ & .000 \\
Customer & Pearson Correlation & .000 & 1 \\
Purchase Interest & Sig. (2-tailed) & & \\
(Y) & & & \\
\hline
\end{tabular}

Source: Primary data processed.

Correlated value of 0.576 means that promotion (X1) partially has a moderate level of influence on Customer Purchase Interest (Y). 
40 Jurnal Ilmiah Ilmu Administrasi Publik: Jurnal Pemikiran dan Penelitian Administrasi Publik Volume 1o Number 1, January- june 2020. Page 35-44

Table 4

Correlation Coefficient Test Results The Effect of Prices on Customer Purchase Interest

Correlations $^{\mathbf{b}}$

\begin{tabular}{llrr}
\hline & & Nilai Harga (X1) & $\begin{array}{c}\text { Minat Beli } \\
\text { Pelanggan (Y) }\end{array}$ \\
\hline Price (X2) & Pearson Correlation & 1 & $.645^{* *}$ \\
& Sig. (2-tailed) & & .000 \\
Customer Purchase & Pearson Correlation & $.645^{* *}$ & 1 \\
Interest (Y) & Sig. (2-tailed) & .000 & \\
\hline Source: Cun
\end{tabular}

Source: Customer Purchase Interest Primary data processed.

The results in table 4 obtained a correlation value of 0.645 . This shows that the price variable (X2) partially has a strong influence on Customer Purchase Interest (Y).

Table 5

Correlation Coefficient Test Results Effect of Promotion and Price together on Customer Purchase Interest

Model Summary

\begin{tabular}{lrrrr}
\hline Model & $\mathrm{R}$ & R Square & $\begin{array}{c}\text { Adjusted R } \\
\text { Square }\end{array}$ & \multicolumn{2}{c}{ Std. Error of the Estimate } \\
\hline 1 & $.695^{\mathrm{a}}$ & .483 & .472 & 2.635 \\
\hline
\end{tabular}

Source: Primary data processed

Based on the results in the table above obtained a correlation value of 0.695 . This shows that the promotion variable (X1) and price (X2) together have a strong degree of influence on Customer Purchase Interest (Y).

\section{Analysis of the Coefficient of Determination}

Detemination coefficient analysis is used to determine the magnitude of influence between independent variables on the dependent variable. The results of data processing can be explained as follows:

Table 6

Determination Coefficient Test Results Influence of Promotion of Purchase Interest

Model Summary

\begin{tabular}{llrrr}
\hline Model & R & R Square & $\begin{array}{c}\text { Adjusted R } \\
\text { Square }\end{array}$ & \multicolumn{2}{c}{$\begin{array}{c}\text { Std. Error of the } \\
\text { Estimate }\end{array}$} \\
\hline 1 & $.576^{\mathrm{a}}$ & .332 & .325 & \multicolumn{2}{c}{2.979} \\
\hline
\end{tabular}

Source: Primary data processed 
Based on the results in the table above obtained R Square value of 0.332. This shows that the contribution of promotion influence partially on customer buying interest is $33.2 \%$.

\section{Table 7}

Determination Test Results The Effect of Prices on Customer Purchase Interest

\begin{tabular}{|c|c|c|c|c|}
\hline \multicolumn{5}{|c|}{ Model Summary } \\
\hline Model & $\mathrm{R}$ & R Square & $\begin{array}{l}\text { Adjusted R } \\
\text { Square }\end{array}$ & $\begin{array}{l}\text { Std. Error of the } \\
\text { Estimate }\end{array}$ \\
\hline 1 & $.645^{\mathrm{a}}$ & .416 & .410 & 2.785 \\
\hline
\end{tabular}

Source: Primary data processed

Obtained R Square value of 0.416 . This shows that the effect of price partially on buying interest was $41.6 \%$.

\section{Table 8}

Determination Coefficient Test Results Effect of Promotion and Price on Customer Purchase Interest

\begin{tabular}{lcccr}
\multicolumn{6}{c}{ Model Summary } \\
\hline Model & R & R Square & $\begin{array}{c}\text { Adjusted R } \\
\text { Square }\end{array}$ & \multicolumn{2}{c}{$\begin{array}{c}\text { Std. Error of the } \\
\text { Estimate }\end{array}$} \\
\hline 1 & $.695^{\mathrm{a}}$ & .483 & .472 & 2.635 \\
\hline
\end{tabular}

Source: Primary data processed

Based on the results in the table above obtained R Square value of 0.483 . This shows that the contribution of promotion influence partially on customer buying interest is $48.3 \%$, while the remaining $51.7 \%$ is influenced by other factors.

\section{Hypothesis test}

Hypothesis testing is intended to determine whether the hypothesis should be accepted or rejected. In this test used the $t$ test (partial) and $F$ test (simultaneous). Hypothesis testing partially in this study uses the $t$ test to test how the influence of each independent variable individually to the dependent variable.

\section{Table 9}

Hypothesis Testing Promotional Variables on Customers' Purchase Interests

Coefficients $^{\mathrm{a}}$

\begin{tabular}{|c|c|c|c|c|c|}
\hline \multirow[t]{2}{*}{ Model } & \multicolumn{2}{|c|}{ Unstandardized Coefficients } & $\begin{array}{r}\text { Standardized } \\
\text { Coefficients }\end{array}$ & $\mathrm{t}$ & Sig. \\
\hline & B & Std. Error & Beta & & \\
\hline 1 (Constant) & 20.160 & 2.756 & & 7.315 & .000 \\
\hline Promosi (X1) & .499 & .072 & .576 & 6.974 & .000 \\
\hline
\end{tabular}

Source: Primary data processed 
42 Jurnal Ilmiah Ilmu Administrasi Publik: Jurnal Pemikiran dan Penelitian Administrasi Publik
Volume 10 Number 1, January- june 2020. Page 35-44

Obtained $\rho$ value $0,000<0.05$. Thus the first hypothesis which states that there is a positive and significant influence between promotion of Customers' Purchase Interests can be accepted.

Table 10

Price Variable Hypothesis Testing of Customers' Purchase Interests

Coefficients $^{\mathrm{a}}$

\begin{tabular}{|c|c|c|c|c|c|}
\hline \multirow[t]{2}{*}{ Model } & \multicolumn{2}{|c|}{$\begin{array}{l}\text { Unstandardized } \\
\text { Coefficients }\end{array}$} & \multirow{2}{*}{$\begin{array}{c}\begin{array}{c}\text { Standardized } \\
\text { Coefficients }\end{array} \\
\text { Beta } \\
\end{array}$} & \multirow[t]{2}{*}{$\mathrm{t}$} & \multirow[t]{2}{*}{ Sig. } \\
\hline & $\mathrm{B}$ & Std. Error & & & \\
\hline 1 (Constant) & 15.176 & 2.897 & & 5.239 & .000 \\
\hline Harga (X2) & .626 & .075 & .645 & 8.357 & .000 \\
\hline
\end{tabular}

Source: Primary data processed

Obtained $\rho$ value $0,000<0.05$. Thus the second hypothesis which states that there is a positive and significant influence between price on Customers' Purchase Interests can be accepted. Hypothesis testing together is intended to determine the effect of all independent variables on the dependent variable, namely promotion and price on Customers' Purchase Interests. In this test, the F test is used.

Table 11.

Simultaneous Hypothesis Testing

\begin{tabular}{llrrrr}
\multicolumn{7}{c}{ ANOVA $^{\mathbf{a}}$} & & \\
\hline Model & Sum of & df & Mean Square & F & Sig. \\
& Squares & & & & \\
\hline 1 Regression & 628.357 & 2 & 314.178 & 45.259 & $.000^{\mathrm{b}}$ \\
& 673.353 & 97 & 6.942 & & \\
Residual & 1301.710 & 99 & & & \\
Total & & & &
\end{tabular}

Source: Primary data processed

Based on the above data processing results obtained $\rho$ value $0,000<0.05$, thus the third hypothesis which states that there is a positive and significant effect between promotion and price together on Customers' Purchase Interests can be accepted.

\section{CONCLUSION}

After researchers conducted research and analysis on the effect of Promotion and Price on Customer Purchase Interest at PT. Sumber Cipta Multiniaga South Jakarta Branch, it can be concluded that promotion has a positive and significant effect on Customer Purchase Interest. This can be seen from $\rho$ value $0,000<0.05$. Promotion has a positive correlation with customer buying interest of 0.576 with a moderate level of influence power and a contribution of $33.2 \%$ on Customer Purchase Interest. Hypothesis testing obtained $\rho$ value $0,000<0.05$. Price has a 
positive and significant effect on Customer Purchase Interest. this can be seen from $\rho$ value $0,000<0.05$. price has a positive correlation with customer buying interest of 0.645 with a strong degree of influence strength and a contribution of $41.6 \%$ influence on Customer Purchase Interest. Hypothesis testing obtained $\rho$ value $0,000<0.05$. Promotions and prices together have a positive and significant effect on Customer Purchase Interest. This can be seen $\rho$ value 0,000 $<0.05$. Promotion and price together have a positive correlation with Customer Purchase Interest of 0.695 with a strong degree of influence strength and contribution of influence of $48.3 \%$ on Customer Purchase Interest. The multiple regression model obtained is $\mathrm{Y}=11.373+0.271 \mathrm{X} 1+$ $0.456 \mathrm{X} 2$ which means that if the promotion and price increase, the Customer Purchase Interest will also increase.

\section{REFERENCES}

Al Badi, K. S. (2015). The Dimensions of Marketing Mix. Management and Organizational Studies. https://doi.org/10.5430/mos.v2n1p136

Arikunto. (2010). Metodelogi Penelitian. Pendekatan Penelitian.

Deng, Y., Staelin, R., Wang, W., \& Boulding, W. (2018). Consumer sophistication, word-ofmouth and "False" promotions. Journal of Economic Behavior \& Organization, 152, 98123. https://doi.org/https://doi.org/10.1016/j.jebo.2018.05.011

Eko Purnomo, Y. 'Aini M. (2016). Pengaruh Harga, Kualitas Produk Dan Lokasi Terhadap Minat Beli Konsumen Dalam Membeli Beras Lokal (Studi Kasus Desa Rambah Utama). Jurnal Mahasiswa Prodi Manajemen Fakultas Ekonomi.

Ghozali, I. (2018). Aplikasi Analisis Multivariate dengan Program IBM SPSS 25.

Hasnelly, \& Yusuf, E. (2012). Analysis of Market-Based Approach on the Customer Value and Customer Satisfaction and Its Implication on Customer Loyalty of Organic Products in Indonesia. Procedia - Social and Behavioral Sciences, 40, 86-93. https://doi.org/https://doi.org/10.1016/j.sbspro.2012.03.165

Kasali, R. (1992). Manajemen Periklanan. Manajemen Periklanan.

Kotler, P., \& Keller, K. L. (2009). Marketing management (13th ed.). In Prentice Hall.

Lupiyoadi, R. (2013). Manajemen Pemasaran Jasa: Berbasis Kompetensi Edisi 3. Penerbit Salemba.

Minarti, S. N., \& Segoro, W. (2014). The Influence of Customer Satisfaction, Switching Cost and Trusts in a Brand on Customer Loyalty - The Survey on Student as im3 Users in Depok, Indonesia. Procedia - Social and Behavioral Sciences, 143, 1015-1019. https://doi.org/https://doi.org/10.1016/j.sbspro.2014.07.546

Morris, D. (1980). A note on pricing and promotional strategies for a firm operating in dual markets. Omega, 8(6), 699-700. https://doi.org/https://doi.org/10.1016/03050483(80)90014-6

Peter, J. P., Olson, J. C., \& Grunert, K. G. (1999). Consumer behaviour and marketing strategy. 
44 Jurnal Ilmiah Ilmu Administrasi Publik: Jurnal Pemikiran dan Penelitian Administrasi Publik Volume 10 Number 1, January- june 2020. Page 35-44

McGraw-hill London.

Purnasari, H., \& Yuliando, H. (2015). How Relationship Quality on Customer Commitment Influences Positive e-WOM. Agriculture and Agricultural Science Procedia, 3, 149-153. https://doi.org/https://doi.org/10.1016/j.aaspro.2015.01.029

Sandi Winarto, S., Sutojo, T., kunci, K., Mobil Bekas, H., Mamdani, F., \& Syaraf Tiruan, J. (2012). Menentukan Harga Mobil Bekas Dengan Menggunakan Metode Fuzzy Mamdani Dan Metode Jaringan Syaraf Tiruan. Techno.COM Agustus.

Santoso, S. (2012). Panduan Lengkap SPSS Versi 20. In PT Elex Media Komputindo.

Satria, A. A. (2017). Pengaruh Harga, Promosi, dan Kualitas Produk Terhadap Minat Beli Konsumen Pada Perusahaan a-36. Jurnal Manajemen Dan Start-Up Bisnis.

Scriven, J., Clemente, M., Dawes, J., Trinh, G., \& Sharp, B. (2017). Buying brands at both regular price and on promotion over time. Australasian Marketing Journal (AMJ), 25(4), 252-260. https://doi.org/https://doi.org/10.1016/j.ausmj.2017.10.006

Suardana, W., Suni, M., \& Ridwan, M. (2020). The Influence of Room Prices and Promotion Costs on Hotel Room Occupancy Rates in Palopo City, South Sulawesi. Jurnal Ad'ministrare, 6(2), 123-130.

Sugiyono. (2012). Metode Penelitian Kuantitatif, Kualitatif dan R \& D.Bandung:Alfabeta. Metode Penelitian Kuantitatif, Kualitatif Dan $R \quad \& \quad$ D.Bandung:Alfabeta. https://doi.org/10.1017/CBO9781107415324.004

Sumarwan, U. (2003). Perilaku Konsumen: Teori dan penerapannya dalam Pemasaran. Ghalia Indonesia, Jakarta.

Sutisna. (2003). Perilaku Konsumen: Teori dan penerapannya dalam Pemasaran. Ghalia Indonesia, Jakarta. https://doi.org/10.1007/BF01013984 